\title{
Source-sink relationships during early crop development influence earliness of sugar accumulation in sugarcane
}

\author{
Julio V. Saez ${ }^{1, *}$, , Jorge A. Mariotti ${ }^{2}$ and Claudia R. C. Vega ${ }^{3}$ (iD \\ ${ }^{1}$ INTA, EEA Famaillá, Ruta Provincial 301, km 32, Tucumán (4132), Argentina \\ 2 FCNa, UNSa, Av. Bolivia 5150, Salta (4400), Argentina \\ ${ }^{3}$ INTA, EEA Manfredi, Ruta Nacional Nº 9, km 636 (5988) Córdoba, Argentina \\ * Correspondence: saez.julio@inta.gob.ar
}

Received 20 July 2018; Editorial decision 14 May 2019; Accepted 20 May 2019

Editor: Greg Rebetzke, CSIRO Agriculture and Food, Australia

\begin{abstract}
In subtropical environments where sugarcane (Saccharum spp.) crops are frequently limited by the duration of the growth cycle, earliness in maturity is a key genotypic trait. Using the concept of source-sink relationships, we hypothesised that earliness is controlled by the dynamics of tillering (DT), which define sink strength early in the growth cycle. Five modern commercial sugarcane genotypes with similar sucrose yields and varying degrees of earliness in ripening were grown in the field over three years and their DT, dynamics of sucrose accumulation (DS), and sourcesink relationships over time were characterised. Canonical correlations and principal components analysis revealed that DT explained $68 \%$ of the total variance in DS. Early ripening genotypes exhibited the shortest thermal time to the end of tiller mortality $\left(\boldsymbol{\theta T i l} I_{\text {mort }}\right)$, the lowest tiller survival and millable tiller number, and greatest sugar content at $\theta$ TiI $_{\text {mort }}$ $\left(S_{\text {conc, }}\right.$, Til $\left._{\text {morr }}\right)$. The rate and duration of the sucrose accumulation phase did not explain the genotypic variation either in final sugar content or in earliness when considered in isolation without taking into account the effect of $S_{\text {conc, }}$ Til $_{\text {mort }}$. In the set of genotypes examined, the variation in final sucrose yield was most explained by the variation in stalk number. We conclude that the dynamics of tiller appearance and senescence modified the early source-sink relationships and thus determined the differential sucrose contents around $\theta$ TiI $_{\text {mort }}$ and the earliness of maximal sugar accumulation. $\boldsymbol{\theta T i l}_{\text {mort }}$ which was closely associated with the 14-leaf phenological stage, emerged as a candidate trait to screen for genotypic variation in early ripening, crop cycle duration, and yield.
\end{abstract}

Keywords: Genotypic traits, sucrose accumulation dynamics, ripening, Saccharum, sugar yield, tillering.

\section{Introduction}

Commercial hybrid sugarcane (Saccharum spp.) is considered one of the most efficient crops for biomass production (Waclawovsky et al., 2010) and its economic importance is currently increasing because of its convenience as a bioenergy crop (Sabatier et al., 2015). Development of new adapted genotypes with increased sugar yield has been achieved by means of increases in biomass at harvest (Muchow et al., 1994; Jackson, 2005; Acreche et al., 2015; Acreche, 2017) or increases in the extractable sugar content (Edme et al., 2005; Ming et al., 2006). In subtropical areas where growing seasons for sugarcane crops are generally short (up to 9-11 months) due to low temperatures or freezing stress (Eggleston et al., 2004), earliness of crop ripening is also an important selection criterion for new cultivars (Mariotti, 2001; Singh and Singh, 2004). Earliness in ripening can be defined as a genotypic attribute associated with the time to maximum sucrose content during the growing 
season (Elibox, 2012b; Gilbert et al., 2006). Earliness is not only a valuable trait in short-season areas but it is also important for bringing forward the beginning of the annual industrial milling process. Since at the beginning of the milling season the sugarcane sucrose content is usually low, early varieties can contribute to the profitability of the crop since farmers are paid on sucrose extracted rather than on cane biomass (Mamet et al., 1996; Cox et al., 1998). Although it is known that genotypic variability exists for both temporal patterns of sucrose accumulation and the trait of earliness in sugarcane (Elibox, 2012a; Cardozo et al., 2014), the underlying physiological and genetic mechanisms still remain unclear.

A better comprehension of the genetic and physiological basis of earliness would be very beneficial for breeding programs aimed at increasing both sugar content and earliness. Regulation of sucrose metabolism and accumulation in sugarcane has been examined through many different approaches, including agronomical, physiological, biochemical, and genomic (Waclawovsky et al., 2010; Moyle and Birch, 2013; ElSayed et al., 2017). Previous research on sucrose accumulation that has studied contrasting high- versus low-sugar genotypes has considered the potential role of traits associated with patterns of photosynthate allocation between growth and storage functions (Irvine, 1975; Moore, 2005; Lingle et al., 2009; Wang et al., 2013; Marchiori et al., 2014), foliar or stalk elongation rates (Lingle and Irvine, 1994; Mamet and Galwey, 1999; Inman-Bamber et al., 2008), and the form, size, or number of culms at harvest (Sinclair et al., 2005; Lingle and Tew, 2008; Lingle et al., 2009). In addition, factors that reduce crop growth, such as chemical regulators that diminish the elongation rate of internodes (Li, 2004; Caputo et al., 2007; Fong Chong et al., 2010; van Heerden et al., 2015), temperature, water stress, and timing of irrigation (Inman-Bamber, 2004; Singels et al., 2005a, 2005b; Inman-Bamber et al., 2010), all hasten the maturity of internodes (i.e. internodes reaching their final size) and increase the commercial sugar content at later crop stages. The results of these studies support the idea that carbohydrates are mainly diverted to storage rather than to generation of new tissues, crop respiration, or elongation of internodes. Variation in the maximum sugar content has also been associated with changing proportions of young and mature internodes as the crop develops and in response to environmental effects (Lingle and Smith, 1991; Lingle and Irvine, 1994; Inman-Bamber et al., 2002; Lingle and Tew, 2008). Collectively, our current knowledge points towards to an apparent trade-off between structural growth and sucrose storage (Moore, 1995; Mamet and Galwey, 1999) and an important role of source-sink relationships as regulators of sucrose accumulation (Inman-Bamber et al., 2009, 2010; McCormick et al., 2009; Ribeiro et al., 2017; Verma et al., 2017).

Although different approaches have been applied to better understand the source-sink relationships in sugarcane, their effects on sucrose accumulation are still unclear (Moore and Botha, 2013). Several conceptual models have been developed; for example, the allosteric model currently used in studies dealing with enzyme regulation (McCormick et al., 2009) proposes that sucrose accumulation can be limited by the negative feedback control of sinks on photosynthesis (sink limitation).
However, experiments have shown that sucrose accumulation can rise to as high as $67 \%$ of the total dry matter of full, ripened culms even in low-sucrose varieties (Muchow et al., 1996b; Inman-Bamber et al., 2009; Waclawovsky et al., 2010; InmanBamber, 2013), thus reinforcing the idea that partitioning rather than photosynthesis or plant growth is the limiting factor.

Genotypic variation in final sugar content in field-grown crops is well known. Some authors have proposed that it can be explained by a source-sink model that integrates plant photosynthesis (source), elongation rate per plant, and culm number (Inman-Bamber et al., 2009). However, strong quantitative relationships between source-sink dynamics and yield or earliness in ripening have yet to be developed (Singels, 2013). A particular feature of most studies that have examined the sugar accumulation process is that they have analysed processes occurring during the so-called ripening phase (Whittaker and Botha, 1997; Inman-Bamber et al., 2010). The time period when the ripening process begins is not necessarily associated with a fixed phenological stage (Bonnett, 2013). However, there is some evidence that indicates that increases in sucrose accumulation rates occur concomitantly with decreases in the internode elongation rate (Lingle and Irvine, 1994). This approach does not consider the potential role of sinks on the modulation of source-sink relationships early during the establishment of the crop (i.e. when the initial number or size of culms is rapidly changing). During an important time frame in the development of the crop prior to stem elongation, multiple processes modulate sink establishment, including tiller emergence and senescence (van Dillewijn, 1952; Kang et al., 1990; Bell and Garside, 2005; Vasantha et al., 2012, 2014; Bonnett, 2013).

In our current study, we hypothesised that genotypic differences in tillering dynamics (i.e. rates of tillers appearance and mortality) that define the final number of sinks (i.e. millable tillers) will exert a strong effect on the early source-sink relationship, and thus modulate the pattern of sucrose accumulation and the earliness trait of the crop. Our main objectives were to characterise the temporal progress of tillering, sucrose accumulation, and source-sink relationships, and to establish associations between early source-sink relationships and candidate genotypic traits involved in earliness, sucrose accumulation, and yield. We conducted field experiments using modern commercial sugarcane varieties with similar cane and sucrose yields but with different earliness in ripening. Over three seasons, crops were grown under the most common row spacing in order to allow the natural expression of genotypic patterns of tillering (emergence, tillering, and senescence of stalks).

\section{Materials and methods}

\section{Experimental location}

One field experiment (Exp 1) was established at Famaillá, Tucumán, Argentina $\left(27^{\circ} 01^{\prime} 78^{\prime \prime} \mathrm{S}, 65^{\circ} 22^{\prime} 59^{\prime \prime} \mathrm{W}, 368 \mathrm{~m}\right.$ above sea level) to study the growth and yield determination of five sugarcane genotypes over three consecutive years. The site is located in one of the most important agro-ecological areas for sugarcane production in Argentina and the soil is an Aquic Argiudoll (Zuccardi and Fadda, 1985). The climate is subtropical with monsoon rainfall distributed from October to April that delivers a total of $1300 \mathrm{~mm}_{\text {year }}{ }^{-1}$. Annual evapotranspiration is $1330 \mathrm{~mm}$ and mean incident solar radiation varies from $8.3 \mathrm{MJ} \mathrm{m}^{-2} \mathrm{~d}^{-1}$ to $18.8 \mathrm{MJ} \mathrm{m}^{-2}$ 
$\mathrm{d}^{-1}$ for June and December, respectively. Mean minimum temperature ranges from $-4{ }^{\circ} \mathrm{C}$ to $18{ }^{\circ} \mathrm{C}$ while maximum temperature ranges from $18^{\circ} \mathrm{C}$ to $32^{\circ} \mathrm{C}$.

\section{Genotypes and crop husbandry}

Five sugarcane hybrid genotypes (Saccharum spp.) were selected from a database of commercially released varieties (INASE, 2015) taking into account their similarity in yield and their contrasting rates of ripening (earliness). All the genotypes were considered as being adapted to the agro-ecological area for this study, although they were initially obtained from crosses elsewhere (Table 1).

At planting (22 August, 2008), 60-cm long stem cuttings with a mean of four buds were planted by hand at a soil depth of $20 \mathrm{~cm}$ with a target bud density of $14.3 \mathrm{~m}^{-2}$. Plots consisted of five rows of $10 \mathrm{~m}$ long and 1.6 $\mathrm{m}$ apart. Crops were grown under rainfed field conditions; water limitation was not expected since the experimental site has access to a water table that fluctuates from $30-80 \mathrm{~cm}$ in depth, and because rainfall was close to the annual crop evapotranspiration. The crops were fertilised each year at the beginning of tillering with $45 \mathrm{~kg} \mathrm{~N} \mathrm{ha}^{-1}$ in the first year and $90 \mathrm{~kg} \mathrm{~N} \mathrm{ha}^{-1}$ in the following years. No additions of $\mathrm{P}$ and $\mathrm{K}$ were made because the soil type is typically rich in these elements and meets the nutritional crop requirements of the crop. In the first year, the crop that originated from the stem cuttings (hereafter referred to as plant crops, PC) was harvested on 9 September 2009. In subsequent years, crops from regrowth (i.e. regenerated from the subterranean buds; hereafter referred to as ratoon crops, RC) were harvested on 2 September 2010 (RC1) and 25 August 2011 (RC2). We refer to PC, RC1, and RC2 collectively as the 'crop class'.

\section{Crop phenological development}

Crop development and timing to critical phenological events as affected by genotype and temperature variation among growing seasons was expressed on the basis of thermal time (day-degrees, ${ }^{\circ} \mathrm{Cd}$; Ritchie and $\mathrm{Ne}$ Smith, 1991).

To examine whether genotypes differed in their base temperature for development ( $T_{\text {base }}$, the lowest temperature below which no development occurs) we conducted an additional experiment under controlled conditions (Exp. 2). Stem cuttings (setts) with a single bud were grown in trays with moist soil substrate in a chamber with controlled temperature and air humidity. Four temperature treatments $(12,21,26$, and $36^{\circ} \mathrm{C}$ ) were applied using a split-plot design with six repetitions. The main plot was temperature and the sub-plot was the genotype. Setts were examined daily and the time taken to reach a $1-\mathrm{cm}$ long sprout (shoot emergence) in at least $50 \%$ of cuttings was recorded as an estimate of the initiation of development. For each genotype, a linear regression was fitted to the relationship between development rate (inverse of time to $1-\mathrm{cm}$ sprout) and temperature; and $T_{\text {base }}$ was then determined by extrapolation to the temperature below which development was zero (Ritchie and Ne Smith, 1991).
In addition, crop phenology in Exp 1 was monitored at 2-week intervals for five primary stalks randomly selected and tagged at the sprouting phase. At each sampling date, the thermal time and the number of fully expanded leaves (i.e. with visible ligules) were recorded.

For simplicity, thermal time was calculated as the summation of mean daily temperature minus $T_{\text {base }}$ as long as the mean temperature was greater than $T_{\text {base }}$ (Ritchie and Ne Smith, 1991, Bonhomme, 2000). We chose to use a single $T_{\text {base }}$ (i.e. for development initiation; Exp2) rather than varying it for different phenological phases (e.g. tillering) to avoid potential confounding effects of changes in phyllochron, crop architecture, or growth patterns on the duration of phenological phases. The approximation of using a single value of $T_{\text {base }}$ to represent development throughout the crop life cycle is common in sugarcane crop modelling, both as a fixed (e.g.APSIM-Sugarcane model) or a genotype-dependent (DSSAT/CANEGRO) parameter (Keating et al., 1999; O’Leary, 2000; Dias et al., 2019).

\section{Temporal dynamics of tillering}

Tiller emergence and senescence were recorded as the evolution of tiller density over time until harvest. The number of living tillers was monitored non-destructively in the three central rows of each experimental plot at 15- $d$ intervals until the fourth month after crop emergence, and then at $30-\mathrm{d}$ intervals until harvest. A tri-linear model describing stalk density as a function of thermal time $\left(\theta,{ }^{\circ} \mathrm{Cd}\right)$ was fitted for each experimental plot:

$$
\begin{gathered}
T i l_{\mathrm{N}}=a+T i l_{\mathrm{rate}} \times \theta, \text { for } \theta \leq \theta T i l_{\mathrm{N}, \text { max }} \\
T i l_{\mathrm{N}}=a+T i l_{\mathrm{rate}} \times \theta T i l_{\mathrm{N}, \text { max }}+M_{\mathrm{rate}} \times\left(\theta-\theta T i l_{\mathrm{N}, \max }\right), \\
\text { for } \theta T i l_{\mathrm{N}, \text { max }}<\theta \leq \theta T i l_{\mathrm{mort}} \\
T i l_{\mathrm{N}}=a+T i l_{\mathrm{rate}} \times \theta T i l_{\mathrm{N}, \text { max }}+M_{\mathrm{rate}} \times\left(\theta T i l_{\text {mort }}-\theta T i l_{\mathrm{N}, \max }\right), \\
\text { for } \theta>\theta T i l_{\text {mort }}
\end{gathered}
$$

where $T i l_{\mathrm{N}}$ is the number of live tillers per surface area $\left(\mathrm{m}^{2}\right), a$ is the function intercept, $T i l_{\text {rate }}$ and $M_{\text {rate }}$ are the rates of tiller appearance and mortality, respectively. $\theta T i l_{\mathrm{N}, \max }$ represents the thermal time from crop emergence to the moment when the maximum tiller number is reached, and $\theta T i l_{\mathrm{N}, \text { mort }}$ represents the thermal time from crop emergence to the moment when tiller mortality ends, i.e. when the final (surviving) number of tillers is reached (i.e. $\left.T i l_{\mathrm{N}, \text { final }}\right)$. A full list of variables is given in Table 2 .

$\theta T i l_{\mathrm{N}, \max }$ and $\theta T i l_{\text {mort }}$ were calculated for the times at which the maximum and final tiller numbers were recorded, respectively. Percent tiller mortality $(\% M)$ was estimated as $\% M=\left(T i l_{N, \max }-T i l_{\mathrm{N}, \text { final }}\right) / T i l_{\mathrm{N}, \max } \times 100$. From Eq 1, the duration (in thermal time) of the tiller mortality phase $\left(\theta M_{\text {dur }}\right)$ was estimated as $\theta T i l_{\text {mort }}-\theta T i l_{\mathrm{N}, \max }$.

The temporal dynamics of tillering (DT) for each genotype and crop class (i.e. plant or ratoon crops) were represented and analysed statistically by the following parameters: tillering rate $\left(T i l_{\text {rate }}\right)$, duration of the tillering

Table 1. Origin (breeding programs and sites of selection), earliness of maturity (ripening behaviour) and typical harvest time for the five hybrid sugarcane (Saccharum spp.) genotypes used in this study

\begin{tabular}{llll}
\hline Genotype & Breeding program and site selection & Earliness of maturity & Harvest month \\
\hline INTA NA 89-686 & $\begin{array}{l}\text { Developed by INTA, Tucumán, Argentina, from seeds obtained by Chacra Experimental } \\
\text { Santa Rosa Salta, Argentina (Sopena et al., 2015). }\end{array}$ & Intermediate-late \\
& $\begin{array}{l}\text { Developed by INTA, Tucumán, Argentina, from advanced clones obtained by LSU, } \\
\text { L 91-281 }\end{array}$ & Lasiana, USA (Sopena et al., 2015). & Early July \\
& $\begin{array}{l}\text { Developed by USDA-ARS Houma, Louisiana, USA, advanced clones obtained by the } \\
\text { LCP 85-384 }\end{array}$ & Agricultural Research Service, Canal Point, Florida, USA (Milligan et al., 1994). & Early August \\
RA 87-3 & $\begin{array}{l}\text { Developed jointly by INTA and EEAOC (UIMCA agreement), Tucumán, Argentina } \\
\text { (Costilla et al., 2013). }\end{array}$ & Extra early \\
TucCP 77-42 & $\begin{array}{l}\text { Developed by EEAOC, Tucumán, Argentina, from seeds obtained by the Agricultural } \\
\text { Research Service, Canal Point, Florida, USA (Costilla et al., 2013). }\end{array}$ & Early \\
\hline
\end{tabular}


Table 2. List of variables

\begin{tabular}{|c|c|}
\hline Variable & Definition \\
\hline$C Y$ & Cane yield \\
\hline$M_{\text {rate }}$ & tiller mortality rate \\
\hline$\% M$ & percentage tiller mortality $=\left(T i I_{N, \max }-\left.T i\right|_{N, \text { final }}\right) / T i I_{N, \max } \times 100$ \\
\hline$\theta M_{\text {dur }}$ & duration in thermal time of the tiller mortality phase \\
\hline$S_{\text {conc }}$ & sucrose concentration \\
\hline$S_{\text {conc, } \max }$ & maximum sucrose concentration \\
\hline$S_{\text {conc }, \theta T i / m o r t}$ & sucrose concentration at $\theta$ Til $l_{\text {mort }}$ \\
\hline$\Delta S_{\text {conc }}$ & sucrose accumulation after $\left.T i\right|_{N \text {,final }}$ is reached \\
\hline$S_{\text {dur }}$ & duration in days of the sucrose accumulation phase \\
\hline$S_{\text {rate }}$ & sucrose accumulation rate \\
\hline$\theta S_{\max }$ & thermal time from emergence to maximum sucrose \\
\hline SY & sugar yield \\
\hline$T_{\text {base }}$ & base temperature for development \\
\hline $\mathrm{Til}_{\mathrm{N}}$ & number of living tillers \\
\hline$\left.T^{T}\right|_{N, \text { final }}$ & final tiller number \\
\hline Til $_{\mathrm{N}, \max }$ & maximum tiller number \\
\hline Til rate $_{\text {rat }}$ & tillering rate \\
\hline$\theta \operatorname{TTil}_{\mathrm{N}, \max }$ & thermal time from emergence to maximum tiller number \\
\hline$\theta T i I_{\text {mort }}$ & thermal time from emergence to the end of tiller mortality phase \\
\hline
\end{tabular}

phase $\left(\theta T i l_{\mathrm{N}, \max }\right)$, mortality rate $\left(M_{\mathrm{rate}}\right)$, the duration of the tiller mortality phase $\left(\theta M_{\text {dur }}\right)$, and the duration of the complete tillering phase (i.e. from crop emergence to final tiller number, $\left.\theta T i l_{\text {mort }}\right)$.

In this work, we introduce $\theta T i l_{\text {mort }}$ as a key phenological stage in crop development. It represents a reference developmental stage that allows a more robust comparison among genotypes and crop classes since it removes confounding effects associated with genotypic differences in phenology.

\section{Source-sink relationships}

The source-sink relationships during the period from emergence until $\theta T i l_{\text {mort }}$ were quantified as the quotient between the crop growth rate and the number of tillers. Crop growth rate was calculated as the gain of aerial dry biomass per day $\left(\mathrm{g} \mathrm{m}^{-2} \mathrm{~d}^{-1}\right)$ and was estimated from models of dry biomass accumulation over time fitted to the data obtained from destructive harvests (Supplementary Figure S1 at JXB online). For biomass determination, five destructive harvests were carried out for the PC plants (between 45-271 d from emergence), six for the RC1 plants (87-304 d), and seven for RC2 plants (81-310 d). Each harvest consisted of all plants in an area of $1.6 \mathrm{~m}^{2}$ taken from the central rows of each plot, ensuring that the sampled area was bordered by other plants. The samples were weighed immediately after harvesting and then split in two subsamples. The first sub-sample was again immediately weighed and then subsequently dried at $60^{\circ} \mathrm{C}$ until constant weight in order to determine the relationship between fresh and dry biomass, which was then used to determine the dry biomass of the total sample. The second sub-sample was used to determine sucrose content (see below).

Source-sink relationships were calculated on a daily basis throughout the growing cycle each year. We selected two critical time-points $\left(\theta T i l_{\mathrm{N}, \max }\right.$ and $\theta T i l_{\text {mort }} ;$ eqn 1$)$ to represent the early source-sink relationships and to perform treatment comparisons and multivariate analysis.

\section{Temporal dynamics of sucrose accumulation}

Sucrose determination was carried out at 15-d intervals during the period from early April (PC and RC1) or early March (RC2) until final crop harvest. When sampling dates coincided with biomass determinations, the second sub-sample referred to above was used. Samples of fresh stalks (taken from an area of $1 \mathrm{~m}^{-2}$ in each experimental plot) were milled, and the sucrose content was determined on a fresh-weight basis as the recoverable sugar after stalk extrusion (Meade and Chen, 1977). Sugar content was measured by crushing clean and complete culms (including the apical internodes) using an experimental mill of $150 \mathrm{~kg} \mathrm{~cm}^{-2}$ pressure, which had the capacity to extract $50 \%$ of the juice in the first sample crushing. After filtering and mixing the juice, two 250-ml samplings were analysed for total soluble solids ( ${ }^{\circ}$ Brix; using a Smart-1 refractometer; ATAGO Co. LTD; Japan) and the \% juice sucrose concentration was determined using a digital polarimeter (Polatronic NCE - Germany) after it had been clarified with lead subacetate. Sucrose concentration $\left(S_{\text {conc }}\right)$ was expressed as a percentage of fresh weight of tillers. Cane yield $(C Y)$ was determined as the mean weight of millable tillers from the two last destructive samplings (performed in July and August each year) and expressed in tn $\mathrm{ha}^{-1}$. Sugar yield (SY) was calculated as the product of cane yield and maximum sugar content.

Bilinear models were fitted to the relationship between sucrose concentration and time after $\theta$ Til $l_{\text {mort }}$ :

$$
\begin{gathered}
S_{\text {conc }}=\mathrm{S}_{\text {conc, }, \text { Tilmort }}+\left(S_{\text {rate }} \times t\right), \text { for } t \leq S_{\text {dur }} \\
S_{\text {conc }}=\mathrm{S}_{\text {conc, }, \text { Tilmort }}+\left(S_{\text {rate }} \times S_{\text {dur }}\right), \text { for } t>S_{\text {dur }}
\end{gathered}
$$

Where $t$ is time (d) from the end of tiller mortality, and $S_{\text {conc, } \theta \text { Tilmort }}$ and $S_{\text {rate }}$ represent the sucrose concentration at the end of tiller mortality and the sucrose accumulation rate), respectively. $S_{\text {dur }}$ represents duration (d) of the true ripening phase, i.e. the time interval between $S_{\text {conc, } \theta \text { Tilmort }}$ and the point at which the maximum sugar content is reached, $S_{\text {conc,max }}$

Sucrose accumulation after the end of tiller mortality $\left(\Delta S_{\text {conc }}\right)$ was calculated as $S_{\text {conc, max }}-S_{\text {conc, } \theta \text { Tilmort }}$.

The temporal dynamics of sucrose accumulation (DS) after the end of the tillers mortality was represented and analysed statistically by the following parameters: $S_{\text {conc, } \theta \text { Tilmort }}, S_{\text {rate }}, S_{\text {dur. }}$.

Earliness $\left(\theta S_{\max }\right)$ was quantified as the thermal time that elapsed from crop emergence until the maximum sucrose content was reached. Hence, the highest $\theta S_{\max }$ values correspond to the latest-ripening genotypes.

\section{Experimental design and statistical analysis}

Genotypes were arranged in a randomized complete block design with three replications. Owing to the perennial nature of sugarcane, the same experimental plots were monitored over the three years of the study. We therefore refer to the 'crop class' (CC) to distinguish between the different years, i.e. the first-year growth from planted stem cuttings (PC), and the subsequent two years of re-growth of the ratoon crop, RC1 and RC2.

The dynamics of tillering (DT), sucrose accumulation (DS), and biomass over time were modelled using the Table Curve software (Jandel Scientific, 1991).

To test whether the dynamics of tillering and sucrose accumulation differed among genotypes $(\mathrm{G})$ and crop classes $(\mathrm{CC})$, and to examine potential $\mathrm{G} \times \mathrm{CC}$ interactions, we performed two types of analysis. First, ANOVA and means comparison of the parameters that describe DT and DS (eqns 1,2$)$ and the yield components $\left(T i l_{\mathrm{N}, \max }, T i l_{\mathrm{N}, \text { final }}, \% M, \theta M_{\text {dur }}\right.$, $S_{\text {conc, } \max }, \Delta S_{\text {conc }}, C Y, S Y, \theta S_{\max }$, and source-sink relationships) were investigated through mixed linear models (Di Rienzo et al., 2012). G, CC, and $\mathrm{G} \times \mathrm{CC}$ were set as fixed effects while blocks were considered as random effects. Comparison of means was performed with Fisher's test $(\alpha=0.05)$. Second, to test whether DT and DS as whole processes were different among genotypes and crop classes, a multivariate analysis of variance (MANOVA) was conducted (Camacho Rosales, 1990; Balzarini et al., 2008; Warne, 2014). In this analysis, the parameters describing DT (eqn 1: $a, T i l_{\text {rate }}, \theta T i l_{\mathrm{N}, \max }, M_{\text {rate }}$, and $\theta T i l_{\text {mort }}$ ) or DS (eqn 2: $S_{\text {conc, } \theta T i 1, \text { mort }}$, $S_{\text {rate }}$, and $S_{\text {dur }}$ ) were used as dependent variables while CC, G, and $\mathrm{G} \times \mathrm{CC}$ were considered as sources of variation. Mean vectors comparisons were performed using the Hotelling-Bonferroni test (Balzarini et al., 2008).

To quantitatively determine the connection between DT and DS, a canonical correlation analysis was conducted using the parameters of the fitted models for culm number (independent variables) and sucrose accumulation (dependent variables) (Hotelling, 1936; Ye and Wright, 2010; Dai et al., 2015).

Finally, a multivariate analysis of principal components was fitted to explore correlations among all variables, genotypes, and crop classes. Principal components analysis is a useful tool that has significant advantages over univariate or simple relationships because it allows analysis 
and interpretation of the complete data set as a whole (Di Rienzo et al., 2012). In the bi-plot, two variables have a high correlation when the angle cosine between their vectors is acute (positive correlation) or obtuse (negative correlation). Statistical analysis was performed using the Infostat software (http://www.infostat.com.ar/ (accessed 22 July 2019)).

\section{Results}

\section{Meteorological variables during the crop growing cycles}

Meteorological variables during the three growing seasons are shown in Fig. 1 and were typical of the historical weather in the region. Annual rainfall was 1200, 1174, and $1424 \mathrm{~mm}$ for the first, second, and third year, respectively. Frost stress (temperature $<2{ }^{\circ} \mathrm{C}$ ) occurred in all seasons. While mild frosts occurred in late August 2009 (PC), mild and severe frosts occurred in late June and mid-July in 2010 and 2011 (RC1 and RC2).

\section{Crop phenological development}

In this study, a first step was to characterise the genotypes in terms of their base temperature, $T_{\text {base }}$, for development initiation in order to use thermal time as a descriptor across seasons. Initiation of development includes metabolic processes that are strongly dependent on temperature and genotype when water is not limiting (Bonhomme, 2000). For all genotypes, developmental rates were positively and linearly related to temperature within the range $12-36{ }^{\circ} \mathrm{C}$ used in Exp. 2 to determine $T_{\text {base }}$. $T_{\text {base }}$ did not differ significantly between four of the five genotypes, and they had a mean value of $10.3^{\circ} \mathrm{C}$ (Table 3). Only the late genotype L 91-281 exhibited a significantly lower value $\left(8.3{ }^{\circ} \mathrm{C}\right)$. These values of $T_{\text {base }}$ were in close agreement with

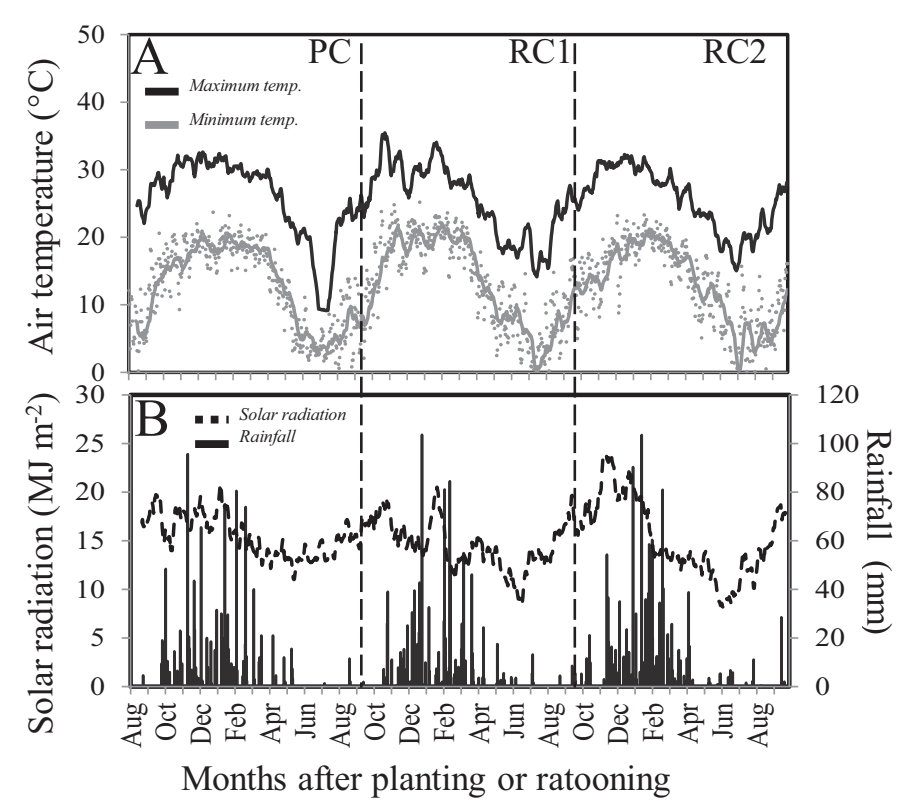

Fig. 1. Seasonal trend of (A) minimum and maximum temperature, and (B) rainfall and daily total solar radiation during three years in which the experiments were conducted at Famaillá, Argentina. PC, plant crop; RC1, first ratoon crop; RC2, second ratoon crop. The dashed vertical lines indicate the emergence of the ratoon crops. previous studies using genotypes adapted to subtropical areas of northern Argentina (Romero et al., 2001), Florida (Sinclair et al., 2004), Queensland (Liu et al., 1998), and Brazil (Hanauer et al., 2014). Other studies, however, have reported significantly higher values ranging from $16-18{ }^{\circ} \mathrm{C}$, for example for South African and Brazilian cultivars (Smit, 2011; Dias et al., 2019). Importantly, a $T_{\text {base }}$ of $\sim 10{ }^{\circ} \mathrm{C}$ is within the range currently used in simulation models $\left(8-12{ }^{\circ} \mathrm{C}\right.$; Keating et al., 1999; O'Leary, 2000). Potential deviations of $T_{\text {base }}$ due to our experimental approximation would have therefore had a relatively small effect on thermal time calculations, and mainly only in those cases when daily mean temperature was lower than the temperature for zero development (Bonhomme, 2000).

\section{Dynamics of tillering}

For most variables associated with tillering dynamics, ANOVA showed significant $\mathrm{G} \times \mathrm{CC}$ interactions, which were basically explained by differences among plant and ratoon crops (Supplementary Table S1A). Hence, analyses were split according to crop class (plant and ratoons; Table 4). For all cases, tri-linear models fitted to plant or ratoon crops accurately $\left(R^{2}>0.94, P<0.001\right)$ described the overall pattern of tiller appearance and senescence from crop emergence to the moment when the final tiller number was determined $\left(\theta T i l_{\text {mort }}\right.$, Fig. 2 , Table 4). Multivariate analysis of variance to test for differences in DT among genotypes within crop classes (i.e. the complete set of parameters describing the evolution of tiller number over time in plant or ratoon crops; eqn 1, test H-B in Table 4) showed significant effects of genotype. Among ratoons, a year effect was found due to small changes in DT in the INTANA 89-686 genotype (Fig. 2). The ranking of genotypes in terms of their DT remained fairly stable across years, particularly within ratoons.

The components of DT (i.e. the individual parameters of the tri-linear models) showed that plant crops (PC) exhibited lower tillering and mortality rates, lower tiller and final stalk number, and lower cane yield than ratoon crops (RC, Table 4). Within ratoons, significant $\mathrm{G} \times \mathrm{CC}$ interactions were found for several variables, but they generally explained small percentages of variance in the data $(\sim 10 \%)$ and were mainly due to changes in the magnitude of responses. In contrast, genotype explained more than $90 \%$ of the data variance for most parameters.

The tillering phase (Fig. 2, Table 4) was significantly longer in PC than in RC $\left(\theta T i l_{\mathrm{N}, \max }=1365.2^{\circ} \mathrm{Cd}\right.$ and $1004.7^{\circ} \mathrm{Cd}$,

Table 3. Base temperature ( $\left.T_{\text {base }}\right)$ for development initiation determined for the five sugarcane genotypes used in this study

\begin{tabular}{ll}
\hline Genotype & Base temperature $\left({ }^{\circ} \mathbf{C}\right)$ \\
\hline INTA NA 89-686 & $10.46 \pm 1.61 \mathrm{ab}$ \\
L 91-281 & $8.25 \pm 1.41 \mathrm{~b}$ \\
LCP 85-384 & $9.61 \pm 0.62 \mathrm{ab}$ \\
RA 87-3 & $10.83 \pm 0.89 \mathrm{a}$ \\
TucCP 77-42 & $10.23 \pm 1.83 \mathrm{ab}$ \\
\hline
\end{tabular}

Different letters indicate significant differences among means (Fisher's test, $\alpha=0.05)$. 


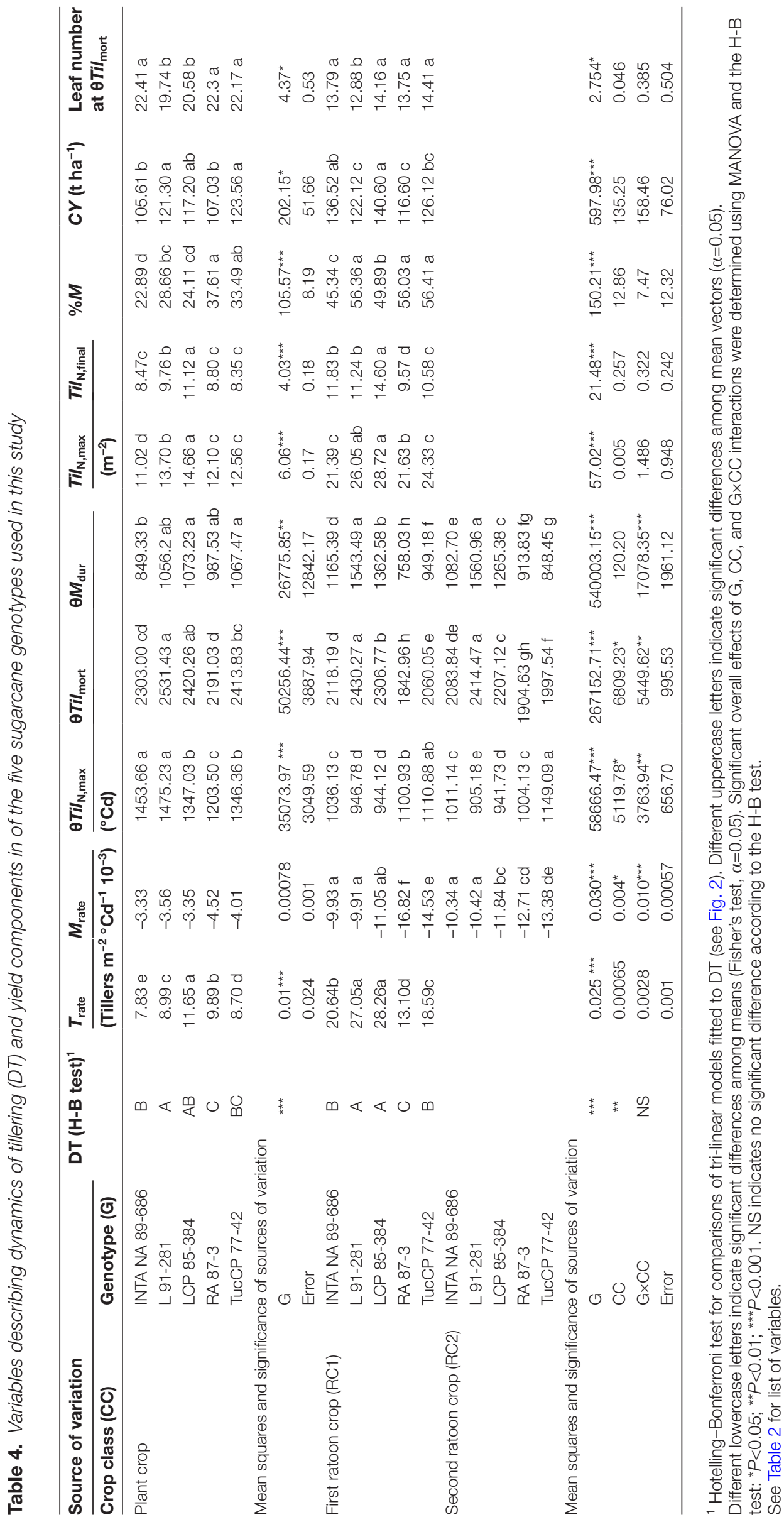



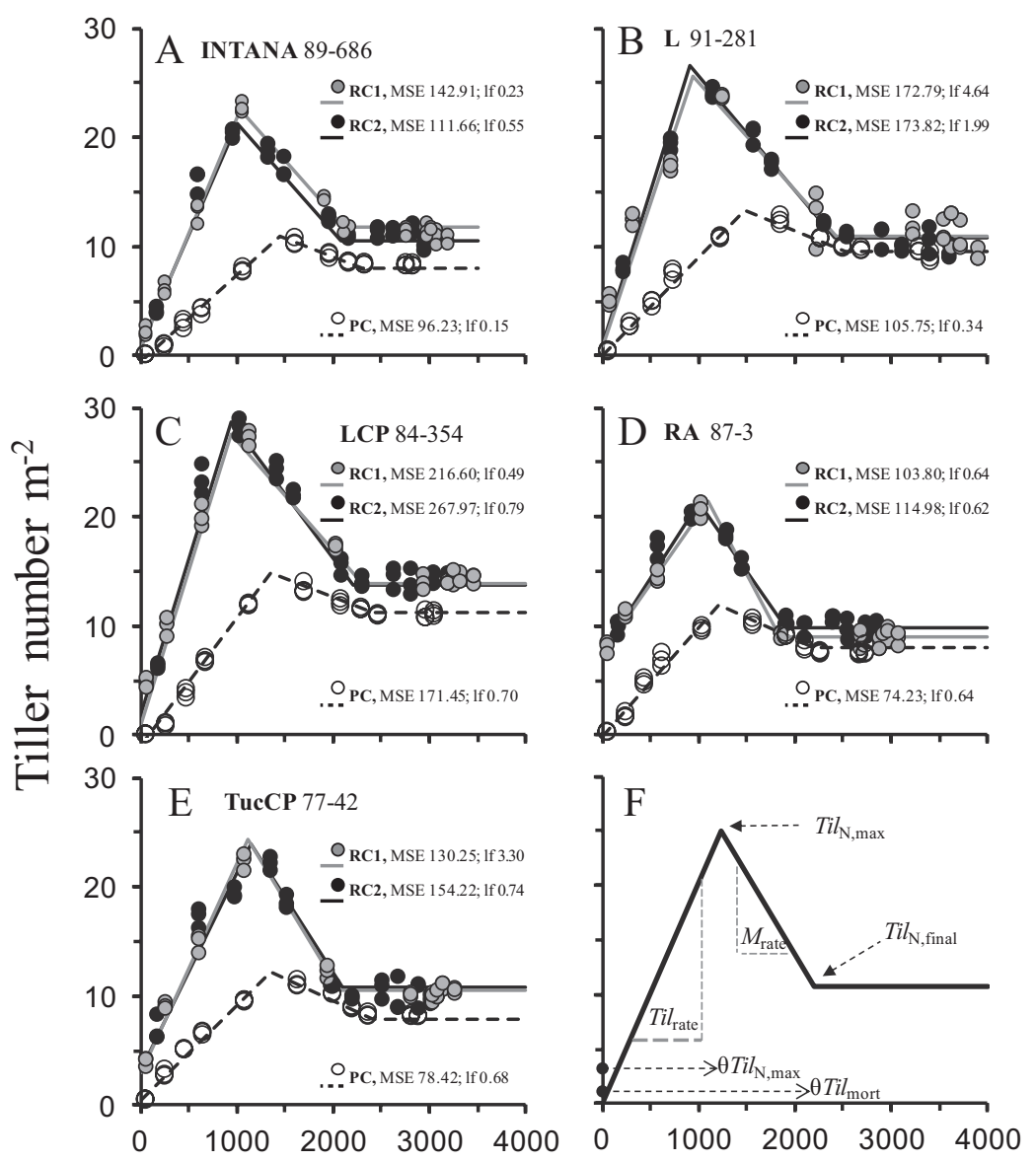

Thermal time from crop emergence $\left({ }^{\circ} \mathrm{Cd}\right)$

Fig. 2. Temporal dynamics of tillering in the five sugarcane genotypes $(A-E)$ over the three years of the experiments. $P C$, plant crop; $R C 1$, first ratoon crop; RC2, second ratoon crop. Symbols indicate observed values and lines show the fitted tri-linear models. (F) Schematic representation of the model and the biological significance of parameters. The base temperature varied among genotypes (Table 3). All fitted models were significant $\left(R^{2}>0.94\right.$;

$P \leq 0.001)$. MSE, mean square error of the model; If, lack of fit. The model parameters and comparisons among genotypes are shown in Table 4.

respectively). In contrast, duration of the tiller senescence phase was longer in $\mathrm{RC}\left(\theta M_{\mathrm{dur}}=1145^{\circ} \mathrm{Cd}\right)$ than in PC $\left(\theta M_{\text {dur }}=1010^{\circ} \mathrm{Cd}\right)$.

Final tiller number was mainly associated with the tillering rate and explained $61 \%$ of the variance in cane yield across all the data (Table 4). Across crop classes, the genotype RA 87-3 had the lowest $T i l_{\mathrm{N}, \text { final }}$ and LCP 85-384 had the highest.

Genotypic differences in DT were associated with $\theta M_{\text {dur }}$, $T i l_{\mathrm{N}, \max }, T i l_{\text {rate }}$, and $\theta T i l_{\text {mort }} \theta T i l_{\text {mort }}$ was a strong variable in defining differences among the genotypes. In ratoon crops, $\theta T i l_{\text {mort }}$ coincided with the 14-leaf crop phenological stage (Table 4) in four of the five genotypes, the only exception being L 91-281 where $\theta T i l_{\text {mort }}$ occurred at the 13-leaf stage.

\section{Dynamics of sucrose accumulation}

For most variables related to sucrose accumulation during the period from $\theta T i l_{\text {mort }}$ to $\theta S_{\max }$, significant effects of G, CC, and $\mathrm{G} \times \mathrm{CC}$ interactions were found (Supplementary Table S1B) and hence analyses were split according to crop class (Table 5). In all cases, bilinear models adequately described the dynamics of sucrose accumulation (DS; Fig. 3, Table 5). Multivariate analysis of variance of DS (H-B in Table 5) showed significant effects of $\mathrm{G}$ and $\mathrm{CC}$ but no significant $\mathrm{G} \times \mathrm{CC}$ interactions, and hence the ranking of genotypes in terms of their patterns of sucrose accumulation was considered stable across years.

Within each crop class, most of the variance for individual variables associated with DS was explained by the genotype effect. Even when they were significant, $\mathrm{G} \times \mathrm{CC}$ interactions explained less than $10 \%$ of the total variance of the data (Table 5).

Genotype RA 87-3 showed the highest sucrose content at $\theta T i l_{\text {mort }}\left(S_{\text {conc, } \theta T i 1, \text { mort }}\right)$ but was one of the slowest genotypes in terms of sucrose accumulation rates. $S_{\text {conc, max }}$ varied between 9-12 $\mathrm{g} \mathrm{g}^{-1}$ and was affected by both CC and G. There were no $\mathrm{G} \times \mathrm{CC}$ interactions for $S_{\text {conc, max }}$ across the three years of the study (Supplementary Table S1B), and it explained $<10 \%$ of the data variance in ratoons. $S_{\text {conc, } \max }$ was higher in ratoons than in plant crops. Genotypes RA 87-3 and TucCP 77-42 had the highest and lowest $S_{\text {conc,max }}$, respectively.

A significant negative relationship between initial sugar concentration and sucrose accumulation rate was found for both crop classes $\left[S_{\text {rate }}=0.124( \pm 0.004)-0.01( \pm 0.001) \times\right.$ $\left.S_{\text {conc, } \theta T i 1, \text { mort }} ; R^{2}=0.74\right]$. Sucrose gain (i.e. $\Delta S_{\text {conc }}$, the difference between $S_{\text {conc,max }}$ and $S_{\text {conc, } \theta \text { Til,mort }}$ ) was accurately described by $S_{\text {dur }}\left(R^{2}=0.85\right)$ or $S_{\text {rate }}\left(R^{2}=0.71\right)$. A multiple regression with both variables $\left(\Delta S_{\text {conc }}=-6.87( \pm 0.79)+92.47( \pm 5.93) \times S_{\text {rate }}\right.$ $\left.+0.071( \pm 0.01) \times S_{\text {dur }} ; R^{2}=0.88\right)$ accurately described the sucrose gain until maximum content was achieved. 


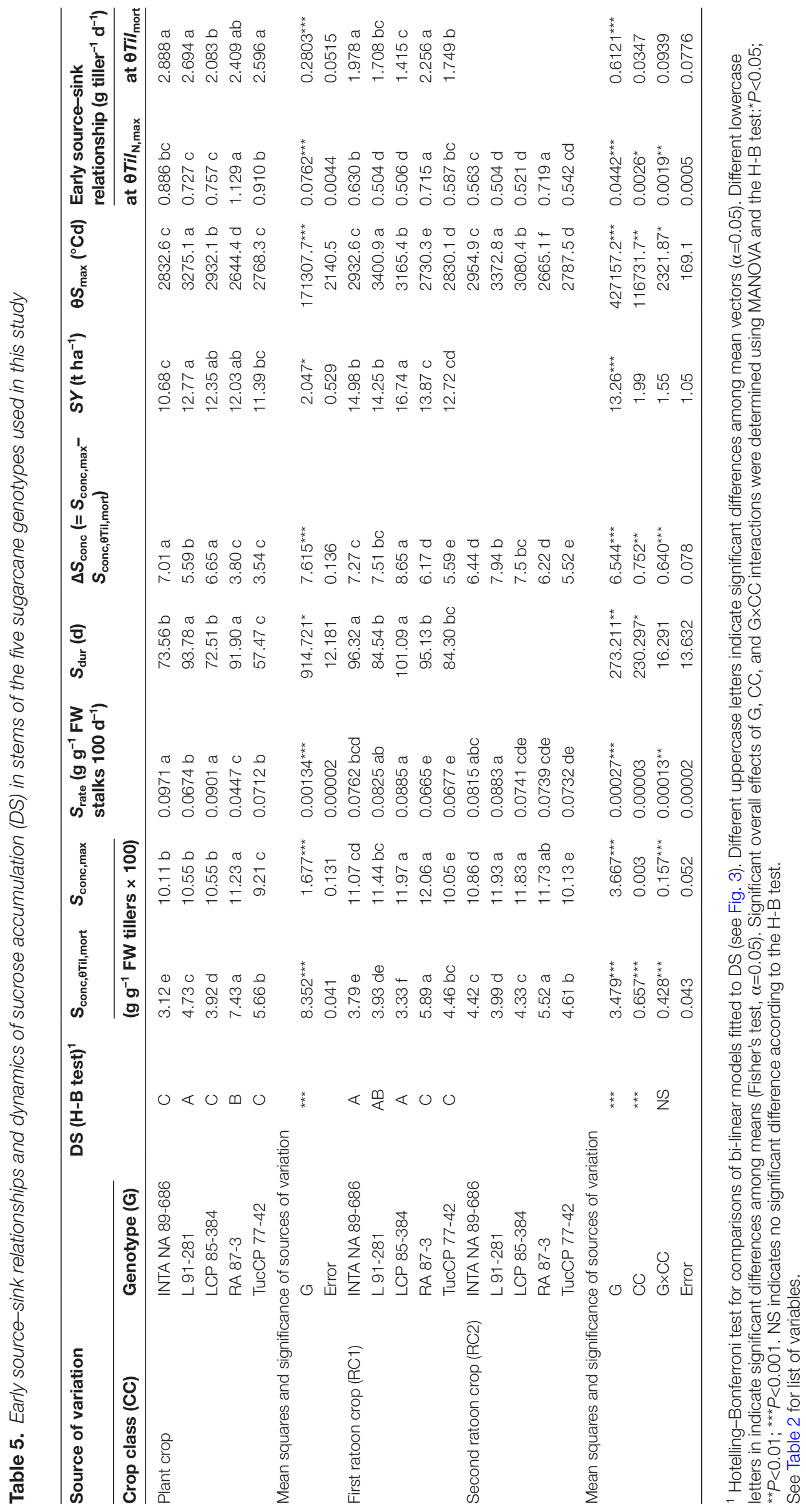




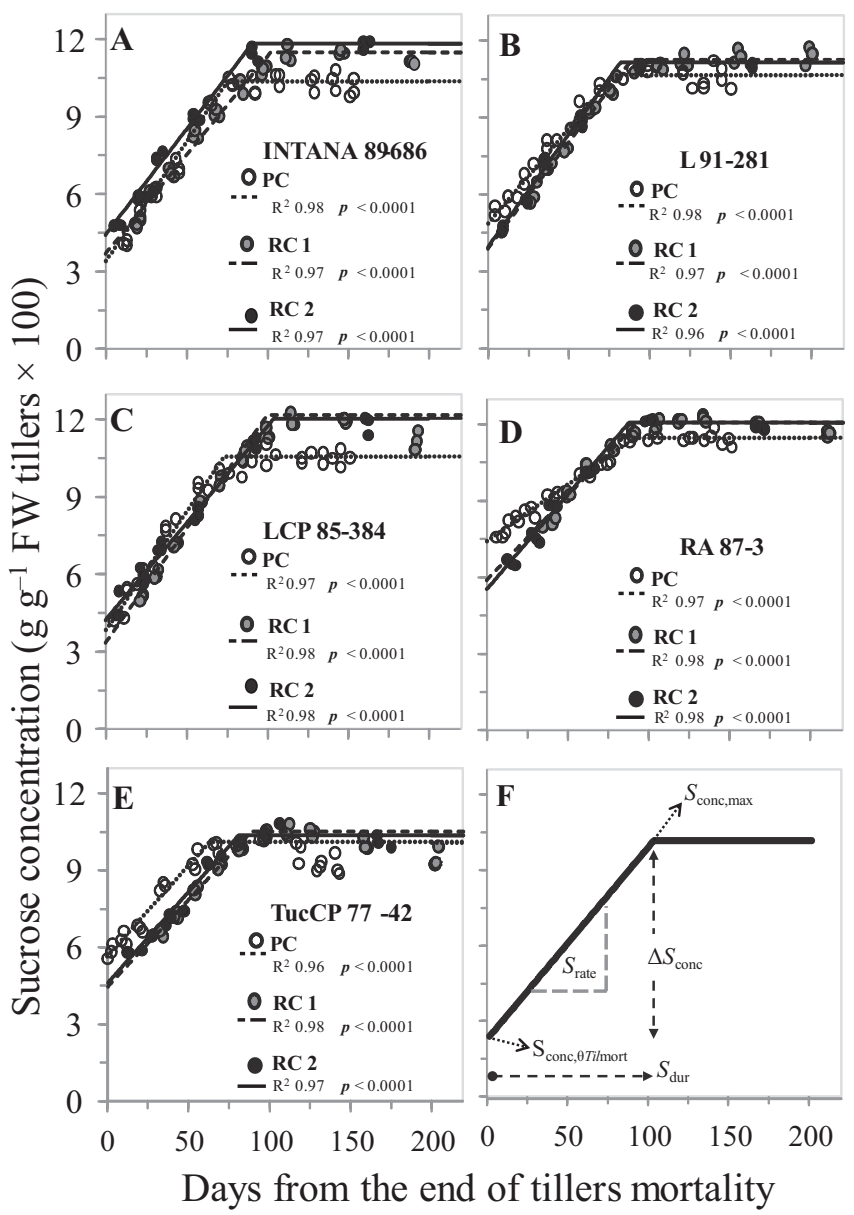

Fig. 3. Dynamics of sucrose accumulation in stems (on a FW basis) of the five sugarcane genotypes (A-E) over the three years of the experiments. $\mathrm{PC}$, plant crop; RC1, first ratoon crop; RC2, second ratoon crop. Symbols indicate observed values and lines show the fitted bilinear models. $(F)$ Schematic representation of the model and biological significance of parameters. The parameters and comparisons among genotypes are shown in Table 5.

Thermal time until the maximum sucrose content $\left(\theta S_{\max }\right)$ was used to quantify earliness, i.e. higher values of $\theta S_{\max }$ were associated with the later-maturing genotypes. $\theta S_{\max }$ varied between $2644{ }^{\circ} \mathrm{Cd}$ and $3458{ }^{\circ} \mathrm{Cd}$ and significant effects of $\mathrm{G}$ and $\mathrm{CC}$ were found.The $\mathrm{G} \times \mathrm{CC}$ interaction was significant but the genotypic effect explained more than $93 \%$ of the total variance in earliness (Table 5). Genotypes RA 87-3 and TucCP 77-42 were found to be the earliest while L 91-281 and LCP 85-384 were the latest.

\section{Source-sink relationships}

Daily source-sink relationships showed two well-defined phases (Fig. 4). During the early stage until $\theta T i l_{\text {mort }}$, sourcesink relationships varied considerably due to changes in the number of tillers (see Fig. 2). The value of the relationship (expressed as g tiller ${ }^{-1} \mathrm{~d}^{-1}$ ) was lowest at $\theta T i l_{\mathrm{N}, \max }$ and became highest and constant at $\theta T i l_{\text {mort }}$ (Fig. 4). Among the crop classes, the source-sink relationships were highest in the plant crops. Genotypic effects always explained most of the variance in the data (Table 5). In ratoon crops, the rank of genotypes in terms of their early source-sink relationship remained fairly stable across years, with L91-281 and LCP 85-384 exhibiting the lowest values and RA 87-3 showing the highest values at both $\theta T i l_{\mathrm{N}, \max }$ and $\theta T i l_{\text {mort }}$.

\section{Association between traits of tillering dynamics, early source-sink relationships, and sucrose accumulation}

Canonical correlation analysis between DT and DS showed that the two dynamics were strongly associated. Two canonical correlations were significant $(P<0.001)$ and explained $68 \%$ and $37 \%$ of the total variance in DS. Associations between DT and DS were more significant when canonical correlation analyses were run for each crop class $\left(R^{2}=0.96\right.$ and $R^{2}=0.88$ for PC and $\mathrm{RC}$, respectively).

A multivariate analysis of principal components was performed to explore the association among all variables that explained the dynamics of stalk establishment, sucrose accumulation, source-sink relationships, and yield (Fig. 5). We chose this type of analytical technique because the resulting bi-plot allows for the simultaneous integration of factors and the identification of associations between variables and genotypes (Balzarini et al., 2008). When considering all the data, the first two principal components explained $76.6 \%$ of the total variation (Fig. 5A). The first principal component split the data according to crop classes, while the second split genotypes according to their earliness and sucrose concentration. Plant crops (circles located to the left in Fig. 5A) exhibited the lowest tillering rates and final tiller number and had higher early source-sink relationship values in comparison to ratoon crops. Ratoons exhibited the highest tillering rates, final stalk number, and sucrose yield. Among the genotypes, RA 87-3 was the earliest maturing (i.e. it had the lowest $\theta S_{\max }$ vector) and showed the highest $S_{\text {conc, }}, \theta_{\text {Til,mort }}$.

Bi-plots constructed separately for plant and ratoon crops increased the analytical power, and explained $71.7 \%$ and 80.6 $\%$ of the data variation, respectively. In both crop classes, the first principal component split genotypes by their earliness in maturity (Fig. 5B, C). The earliest-maturing genotypes RA 87-3 and TucCP 77-42 exhibited the highest source-sink relationship values, the highest $S_{\text {conc, } \theta \text { Til,mort }}$, and the lowest tillering rate (indicated by the obtuse angles among these variables). Genotypes L 91-281 and LCP 85-384 were the latest-maturing (highest $\left.\theta S_{\max }\right)$ and this trait was positively associated with $\theta T_{i l} l_{\text {mort }}$ and tillering rate and negatively associated with early source-sink relationships and $S_{\text {conc, }, \theta \text { Til,mort }}$ (Fig. 5). Cane yield was explained by the final number of millable tillers (Til $\left.l_{\mathrm{N}, \text { final }}\right)$ and the duration of the ripening phase $\left(S_{\text {dur }}\right) \cdot S_{\text {conc, } \theta \text { Til,mort was }}$ not a variable that defined $S_{\text {conc,max }}$, and neither did it explain sugar yield. Interestingly, $S_{\text {conc, } \theta \text { Til,mort }}$ was negatively correlated with $\theta T i l_{\text {mort }}$, earliness, and tillering rates (obtuse angles among these variables), but it was positively correlated with early source-sink relationships. In terms of individual relationships among variables, $S_{\text {conc, } \theta \text { Til,mort }}$ was tightly associated with the early source-sink relationship both at $\theta T i l_{\mathrm{N}, \max }$ (Table $5 ; S_{\text {conc }, \theta T i 1, \text { mort }}=0.13( \pm 0.62)+7.35( \pm 1.06) \times$ Source-sink; $\left.R^{2}=0.63, P<0.001\right)$ and at $\theta T i l_{\text {mort }}\left(S_{\text {conc }, \theta T i l, \text { mort }}=2.38( \pm 0.56)\right.$ $+1.09( \pm 0.30) \times$ Source-sink; $\left.R^{2}=0.32, P=0.0012\right)$. 


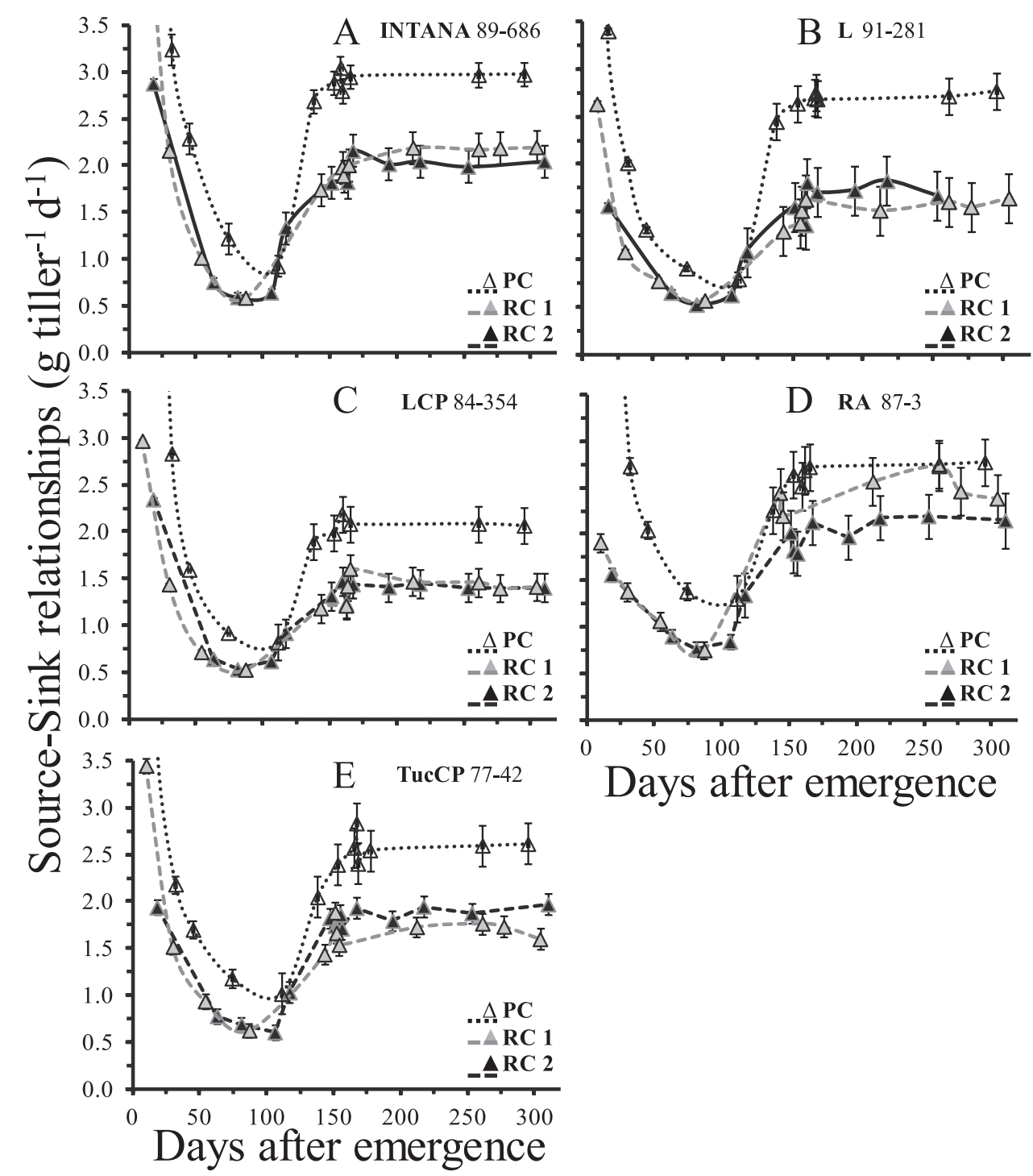

Fig. 4. Evolution of daily source-sink relationships of the five sugarcane genotypes over the three years of the experiments. PC, plant crop; RC1, first ratoon crop; $\mathrm{RC} 2$, second ratoon crop. Data are means $( \pm \mathrm{SE})$ of three replicates.

Environmental variation among years (e.g. temperature) resulted in small changes in three of the four variables describing sucrose accumulation (Table 5). However, these variations did not modify the ranking of genotypes in terms of their earliness in maturity (Table 5, Fig. 5). It is likely that the use of thermal time instead of calendar days and the estimation of $S_{\text {conc, } \theta T i 1, m o r t}$ at $\theta T i l_{\text {mort }}$ would have integrated the potential effects of environmental factors (mainly temperature). Our new source-sink variable most robustly integrated potential environmental effects on crop growth and yield components.

\section{Discussion}

In subtropical environments where sugarcane crops are frequently limited by the duration of the growing season, breeding efforts have to be oriented towards improvements in annual biomass production (Mariotti et al., 2006) and fast photoassimilate partitioning towards storage organs, i.e. sucrose accumulation in stems (Irvine, 1975; Lingle et al., 2009;
Wang et al., 2013; Marchiori et al., 2014). In addition, earliness in maturity is considered a desirable trait because of its contribution to early harvesting and milling (Mamet et al., 1996; Elibox, 2012b; Cardozo and Sentelhas, 2013; Cardozo et al., 2014). In this study, we aimed at establishing links between early and late processes that define yield components (final tiller number, sucrose content) in five modern high-yielding sugarcane genotypes. Field experiments were conducted over three consecutive years (i.e. plant and ratoon crops) in a subtropical environment where rainfall generally meets the crop water demand. Models for tillering dynamics (initiation and senescence), sucrose accumulation and, daily source-sink relationships were constructed to evaluate the genotypic differences. As a first step, we examined the dynamics of tillering (DT) and the dynamics of sucrose accumulation (DS) separately by means of bi- or tri-linear models (Figs 2, 3, Tables 4 , 5 ). We chose this type of model instead of polynomial (InmanBamber, 1994; Gilbert et al., 2006) or logistic ones (Muchow et al., 1996a) in order to quantitatively compare responses in terms of genotype and crop classes (i.e. plant versus ratoon), 


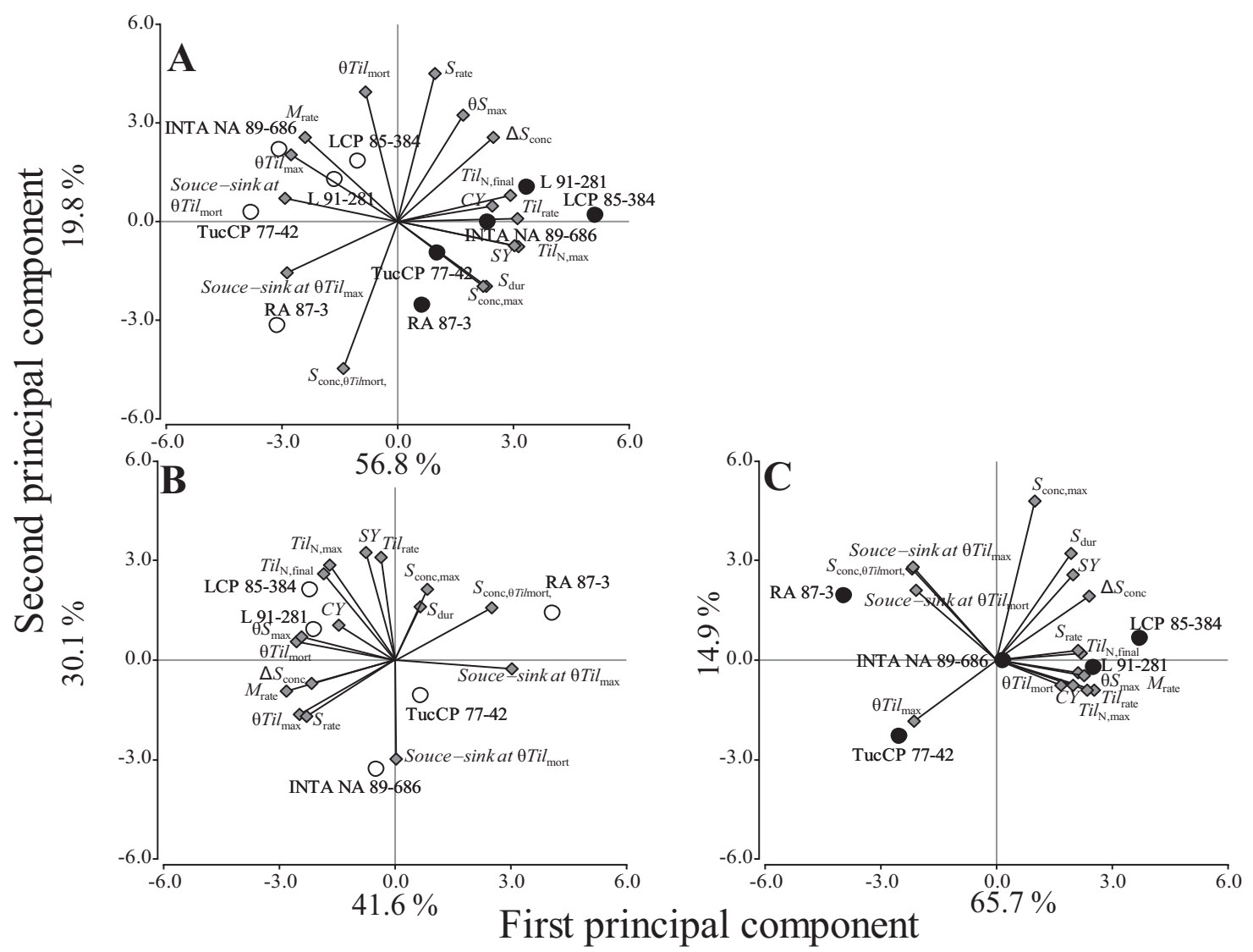

Fig. 5. Biplots of principal component analysis showing relationships between genotypes (circles) and variables (diamonds) that describe tillering dynamics and sucrose accumulation in the five sugarcane genotypes used in this study over three years of experiments. (A) Biplot showing the two crop classes, namely plant crops (open circles) and ratoon crops (filled circles). Individual biplots are shown for plant crops (B) and ratoon crops (C). The parameters and comparisons among genotypes are shown in Tables 4 and 5.

and to seek for meaningful parameters associated with traits and processes that could be used in correlation analysis or for the screening of new genotypes.

For both DT and DS, strong effects of crop class were found, and hence analyses were split according to plant and ratoon crops. In ratoons, the genotypic effect was always the most important factor in explaining variance in the parameters describing DT and DS since no inter-annual effects were found. When analysed as a whole (see the H-B test in Tables 4, 5), DT and DS discriminated genotypes by their consistent performance over this 3-year study. For instance, the genotypes LCP 85-384 and L 91-281 outperformed the other in terms of their tillering ability and stalk numbers but were consistently the latest genotypes in terms of their ripening (i.e. they showed the highest $\left.\theta S_{\max }\right)$.

Among the DT variables, $\theta$ Til mort $_{\text {emerged as a signifi- }}$ cant trait that was strongly associated with tillering rate and final tiller number (Fig. 5). In ratoon crops, $\theta$ Til $l_{\text {mort }}$ coincided with the 14-leaf stage in four of the five genotypes (Table 4). Although more genotypes need to be screened to establish this as a firm relationship, the lack of significant $\mathrm{G} \times \mathrm{CC}$ interactions supports our findings. Because the 14-leaf stage is rather easy to predict using the thermal time approach, we propose that $\theta T i l_{\text {mort }}$ be considered as a key phenological stage when performing genotypic screening. This proposal is made in the context of several studies in sugarcane that have emphasised the relevance of comparing similar sampling dates across seasons to avoid potential effects of crop phenology (Jackson et al., 1995a, 1995b) and to avoid non-repeatable G×CC interactions (Kang et al., 1987; Ramburan et al., 2011, 2013; Ramburan, 2014).

Our observation of a reasonably constant $\theta T i l_{\text {mort }}$ across years and low variance due to G×CC interactions also supports the hypothesis that $\theta T i l_{\text {mort }}$ can be consider as a secondary genotypic trait (Table 4). Although effects of crop class and years were confounded in our study, key variables showed low variance in the $\mathrm{G} \times \mathrm{CC}$ interactions (e.g. $T i l_{\text {rate }}, T i l_{\mathrm{N}, \text { final }}$, source-sink relationships; Tables 4,5 ).

The final tiller number that was set at $\theta T i l_{\text {mort }}$ was a key component in defining cane yield in our set of modern, high-yielding genotypes. The strong genotypic effect for tiller number was well explained by differences in the duration and rate of the tillering phase (Fig. 5C). Interestingly, an apparent trade-off between length of the tillering phase beyond $1000{ }^{\circ} \mathrm{Cd}$ after crop emergence and yield was evident (Figs 2, 5 , Table 4). Genotype L91-281 exhibited the largest $\theta$ Til but this trait did not translate to a higher $T i l_{\mathrm{N} \text {,final }}$ or $C Y$. We hypothesise that an exceptionally large $\theta T i l_{\text {mort }}$ could be associated with asynchronous development of culms. Research by Bell and Garside (2005) demonstrated that synchrony in the development of tillers correlates with higher yields due to a greater proportion of primary stems at harvest. Inverse relationships between tillering rates and the time to maximum 
tillers number ( $T i l_{\text {rate }}$ and $\theta T i l_{N, \text { max }}$, Fig. 5) in our study supported this idea. Hence, high tillering rates coupled with an intermediate $\theta T i l_{\text {mort }}$ appeared to be promising traits to select for high stalk numbers and yield. With our current approach, we were not able to determine which processes determined the rates and durations of the tillering and mortality phases. It is likely that canopy features that control attenuation of solar radiation and light quality at the basal level of the crop might be involved (Singels and Smit, 2002, 2009; Marchiori et al., 2010). Given that gains in yield over time have been more frequently associated with increases in biomass rather than in sugar content (Jackson, 2005; Acreche et al., 2015; Acreche, 2017), a better comprehension of the processes that define stalk number should contribute to future progress in improving yields. Interestingly, stalk number has been suggested to be a highly heritable trait (Kang et al., 1990; Aitken et al., 2008). Among the DS variables, $S_{\text {conc, } \theta \text { Til,mort }}$ appeared to be a second key genotypic trait that explained earliness, although not maximum sugar content $\left(S_{\text {conc,max }}\right)$ or final sugar yield (Figs 3,5$)$. The value of $S_{\text {conc, } \theta T i l, m o r t}$ set at $\sim 5$ months after emergence was $45 \%$ (early genotypes) or 30\% (late genotypes) of the final maximum sucrose measured at harvest. $S_{\text {conc, } \theta \text { Til,mort }}$ was tightly associated with early source-sink relationships, suggesting that the dynamics of stalk generation controlled sugar accumulation at the beginning of the true ripening phase. Considering both components of the source-sink relationship, sink activity (i.e. tillering rate and stalk number) was a stronger variable in explaining $S_{\text {conc, } \theta \text { Til,mort }}$, and hence earliness, than crop growth rate.

The approach that we took for the calculation of early sourcesink relationships is, to our knowledge, new and highlights the potential of $S_{\text {conc, } \theta \text { Til,mort }}$ and $\theta T i l_{\text {mort }}$ as traits to aid in the prediction of sucrose yields early in the growing cycle. We also demonstrated that source-sink relationships vary during crop development in two well-defined phases (Fig. 4). Before $\theta T i l_{\text {mort }}$, the continued changes in sink number modified the daily source-sink relationship, and this process controlled $S_{\text {conc, } \theta T i 1, m o r t}$ (Figs 4, 5). After $\theta T i l_{\text {mort }}$, the source-sink relationship became constant, although it differed among the genotypes.

Previous research in sugarcane has generally analysed processes that control sucrose accumulation during the maturation phase itself (Muchow et al., 1996a; Singels et al., 2005a; Lingle and Tew, 2008; Inman-Bamber et al., 2009) or investigated development, growth, and sucrose accumulation in either separate (Bell and Garside, 2005; Allison et al., 2007) or integrated ways (O'Leary, 2000). Similarly, a vast body of literature has previously considered the idea that genotypic and environmental effects on sucrose accumulation in sugarcane can be explained by the source-sink balance between current photosynthesis and culm growth (Singels and Bezuidenhout, 2002; Inman-Bamber et al., 2009, 2010; McCormick et al., 2009). For example, Inman-Bamber et al. (2009) proposed that final sucrose content depends on how sinks (e.g. in the form of tiller number and plant elongation rate) exert an additional demand for structural assimilates. However, mechanisms for sucrose accumulation have been difficult to quantify because there is not a well-defined phenological stage when accumulation starts and stops (Bonnett, 2013). Our study offers an analytical approach that is able to demonstrate how several aspects of sink determination are involved in defining early source-sink relationships, and thus influence earliness and sucrose yield. Further research focusing on the genetic basis and variability of some traits (e.g. $\theta T i l_{\text {mort }}$, early source-sink relationship, and $\left.S_{\text {conc, } \theta \text { Til,mort }}\right)$ may be useful for improving selection efficiency and in bringing about genetic gains for early genotypes without potential yield penalties.

It is worth emphasising that the genotypes we used in this study all attained typically high maximum sucrose contents (10.05-12.06 \% in ratoon crops, Table 5) and good sugar yields (12.7-16.2 $\mathrm{t} \mathrm{ha}^{-1}$, Table 5) through different strategies. The earliest genotypes RA 87-3 and TucCP 77-42 attained a high $S_{\text {conc, } \theta \text { Til,mort }}$ early in the season, while others exhibited large $S_{\text {rate }}$ (L91-281) or $S_{\text {dur }}$ (INTA NA 89-686). Interestingly, maximum sucrose content was not associated either with the individual variable $S_{\text {dur }}$ or with $S_{\text {rate }}$, because $S_{\text {conc, } \theta \text { Til,mort }}$ was a third critical variable that defined sucrose accumulation (Fig. 3). An unexpected result that merits further research was the negative relationship between $S_{\text {conc, } \theta \text { Til,mort }}$ and the rate of sucrose accumulation during the ripening phase (Fig. 5). While $S_{\text {conc, } \theta \text { Til,mort }}$ seemed to reflect the ability of the crop in establishing early and rapidly changing source-sink relationships, both $S_{\text {dur }}$ and $S_{\text {rate }}$ would mainly reflect late source-sink relationships, i.e. during the ripening phase. During this phase, the carbon demand for structural growth has been fulfilled and hence surplus assimilates in the source would be well represented through $S_{\text {dur }}$ and $S_{\text {rate }}$ (Singels and Bezuidenhout, 2002).

In summary, we have quantitatively demonstrated the links between multiple traits that describe tiller production and senescence, and early sucrose accumulation and yield in five modern subtropical sugarcane genotypes. The use of a multivariate analysis rather than examining individual relationships allowed the multiple links between early and late processes to be determined, together with how they differed among the genotypes. The earliness trait was clearly explained by both $S_{\text {conc, } \theta T i 1, \text { mort }}$ and $\theta T i l_{\text {mort }}$, variables which in turn were positively or negatively associated with early source-sink relationships. In particular, $\theta T i l_{\text {mort }}$ emerged as a genotypic trait involved in the determination of early source-sink relationships. No apparent trade-offs for some key traits for yield determination were found. For instance, $S_{\text {conc,max }}$ or $S_{\text {dur }}$ were not associated (either negatively or positively) with $S_{\text {conc, } \theta \text { Til,mort }}$, earliness, or tiller number. Hence, this suggests that it is possible to select/ breed for improved genotypes by means of the simultaneous selection of those traits (i.e. $S_{\text {conc, } \theta \text { Til,mort }}$ and $S_{\text {dur }}$ ).

\section{Supplementary data}

Supplementary data are available at JXB online.

Table S1. Analysis of variance for the main variables that describe the dynamics of tillering and sucrose accumulation for the five genotypes.

Fig. S1. Crop biomass accumulation in the five genotypes in each of the three years of experiments. 


\section{Acknowledgements}

We are grateful to the field team of INTA's Sugarcane Breeding Program for their logistical assistance in the field, especially to Mr N. Cuello, G. Cuello, and M. Nieva. We thank C.J. Razquin for his collaboration in the construction and interpretation of models, and we are grateful for comments by M.M. Acreche and R. Sopena to improve an early version of this work. We acknowledge numerous contributions made by two anonymous reviewers who helped to improve the final draft. This work is part of a thesis submitted by J.V. Saez in partial fulfilment for the requirements for a doctoral degree at the National University of Córdoba, Argentina, and was supported by the National Agricultural Technology Institute (INTA, projects PNIND 081411 and PNIND1108064), Ministry of Agriculture, Argentina. J.V Saez held a scholarship from INTA.

\section{References}

Acreche MM. 2017. Nitrogen, water and radiation use efficiencies affected by sugarcane breeding in Argentina. Plant Breeding 136, 174-181.

Acreche MM, Saez JV, Chalco Vera J. 2015. Physiological bases of genetic gains in sugarcane yield in Argentina. Field Crops Research 175, 80-86. Aitken KS, Hermann S, Karno K, Bonnett GD, Mclntyre LC, Jackson PA. 2008. Genetic control of yield related stalk traits in sugarcane. Theoretical and Applied Genetics 117, 1191-1203.

Allison JCS, Pammenter NW, Haslam RJ. 2007. Why does sugarcane (Saccharum sp. hybrid) grow slowly? South African Journal of Botany 73, 546-551.

Balzarini MG, Gonzalez L, Tablada M, Casanoves F, Di Rienzo JA, Robledo CW. 2008. Infostat. Manual del Usuario. Córdoba: Editorial Brujas. Bell MJ, Garside AL. 2005. Shoot and stalk dynamics and the yield of sugarcane crops in tropical and subtropical Queensland, Australia. Field Crops Research 92, 231-248.

Bonhomme R. 2000. Bases and limits to using 'degree.day' units. European Journal of Agronomy 13, 1-10.

Bonnett GD. 2013. Developmental stages (phenology). In: Moore PH, Botha FC, eds. Sugarcane: physiology, biochemistry, and functional biology. lowa, USA: John Wiley \& Sons Ltd, 35-53.

Camacho Rosales J. 1990. Interpretación de MANOVA: análisis de la importancia de las variables dependientes. Qurriculum: Revista de teoría, Investigación y Práctica Educativa 1, 107-120.

Caputo MM, De Silva MA, De Beauclair EGF, De Gava GJC. 2007. Sugarcane sucrose accumulation, productivity and flowering using plant regulators. Interciencia 32, 834-840.

Cardozo NP, Sentelhas PC. 2013. Climatic effects on sugarcane ripening under the influence of cultivars and crop age. Scientia Agricola 70, 449-456.

Cardozo NP, Sentelhas PC, Panosso AR, Ferraudo AS. 2014. Multivariate analysis of the temporal variability of sugarcane ripening in south-eastern Brazil. Crop and Pasture Science 65, 300-310.

Costilla DD, Arias ME, García MB, Delgado N, Chavanne ER, Cuenya MI. 2013. Descripción botánica y registro de las variedades de caña de azúcar (Saccharum spp.) TUCCP 77-42, RA 87-3 y LCP 85-384, en el Registro Nacional de Cultivares de la República Argentina. Revista Industrial y Agrícola de Tucumán 90, 51-55.

Cox MC, Ridge DR, Hussey B. 1998. Optimum time of harvest for high early CCS sugar varieties. Proceedings of the Australian Society of Sugar Cane Technology 20, 218-223.

Dai L, Goncalves CMV, Lin Z, et al. 2015. Exploring metabolic syndrome serum free fatty acid profiles based on GC-SIM-MS combined with random forests and canonical correlation analysis. Talanta 135, 108-114.

Dias HB, Inman-Bamber G, Bermejo R, Sentelhas PC, Christodoulou D. 2019. New APSIM-Sugar features and parameters required to account for high sugarcane yields in tropical environments. Field Crops Research 235, 38-53.

Di Rienzo JA, Macchiavelli R, Casanoves F. 2012. Modelos lineales mixtos: aplicaciones en InfoStat. Córdoba: Grupo Infostat.

Edme SJ, Miller JD, Glaz B, Tai PYP, Comstock JC. 2005. Genetic contribution to yield gains in the Florida sugarcane industry across 33 years. Crop Science 45, 92-97.
Eggleston G, Legendre B, Tew T. 2004. Indicators of freeze-damaged sugarcane varieties which can predict processing problems. Food Chemistry 87, 119-133.

Elibox W. 2012a. Determination of the feasibility of commencing the sugarcane (Saccharum spp. hybrids) harvest season in Barbados in January (start of the dry season) instead of the traditional time (mid-February). Tropical Agriculture 89, 199-204.

Elibox W. 2012b. Earliness of sugar accumulation and maturity in modern sugarcane (Saccharum spp. hybrids) clones in the humid tropics. Tropical Agriculture 89, 65-77.

EISayed Al, Lehrer A, Ebrahim M, Mohamed AH, Komor E. 2017. Assessment of sucrose transporters, metabolites and sucrose phosphate synthase in different sugarcane tissues. Physiology and Molecular Biology of Plants 23, 703-712.

Fong Chong B, Mills E, Bonnett G, Gnanasambandam A. 2010. Early exposure to ethylene modifies shoot development and Increases sucrose accumulation rate in sugarcane. Journal of Plant Growth Regulation 29, 149-163.

Gilbert RA, Shine JJM, Miller JD, Rice RW, Rainbolt CR. 2006. The effect of genotype, environment and time of harvest on sugarcane yields in Florida, USA. Field Crops Research 95, 156-170.

Hanauer JG, Streck NA, Langner JA, Kräulich B, UhImann LO. 2014. Leaf development and growth, and yield of sugarcane clones from plant crop and ratoom crop. Bioscience Journal 30, 1077-1086.

Hotelling H. 1936. Relations between two sets of variates. Biometrika 28 , 321-377.

INASE. $(23$ - 11, 2015.) Instituto Nacional de Semillas - Catálogo Nacional de Cultivares - Reg. No 11539, 11540, 11541, 15722 y 15724. https://gestion. inase.gov.ar/consultaGestion/gestiones/index/page:2. (accessed 22 July 2019). Inman-Bamber NG. 1994. Temperature and seasonal effects on canopy development and light interception of sugarcane. Field Crops Research 36, 41-51.

Inman-Bamber NG. 2004. Sugarcane water stress criteria for irrigation and drying off. Field Crops Research 89, 107-122.

Inman-Bamber NG. 2013. Sugarcane yields and yield-limiting processes. In: Moore PH, Botha FC, eds. Sugarcane: physiology, biochemistry, and functional Biology. lowa, USA: John Wiley \& Sons Ltd, 579-600.

Inman-Bamber NG, Bonnett GD, Spillman MF, Hewitt MH, Glassop D. 2010. Sucrose accumulation in sugarcane is influenced by temperature and genotype through the carbon source-sink balance. Crop and Pasture Science 61, 111-121.

Inman-Bamber NG, Bonnett GD, Spillman MF, Hewitt ML, Jackson J. 2008. Increasing sucrose accumulation in sugarcane by manipulating leaf extension and photosynthesis with irrigation. Australian Journal of Agricultural Research 59, 13-26.

Inman-Bamber NG, Bonnett GD, Spillman MF, Hewitt ML, Xu J. 2009. Source-sink differences in genotypes and water regimes influencing sucrose accumulation in sugarcane stalks. Crop and Pasture Science $\mathbf{6 0}$, 316-327.

Inman-Bamber NG, Muchow RC, Robertson MJ. 2002. Dry matter partitioning of sugarcane in Australia and South Africa. Field Crops Research 76, $71-84$.

Irvine JE. 1975. Relations of photosynthetic rates and leaf and canopy characters to sugarcane yield. Crop Science 15, 671-676.

Jackson PA. 2005. Breeding for improved sugar content in sugarcane. Field Crops Research 92, 277-290.

Jackson P, McRae T, Hogarth M. 1995a. Selection of sugarcane families across variable environments I. Sources of variation and an optimal selection index. Field Crops Research 43, 109-118.

Jackson P, McRae T, Hogarth M. 1995b. Selection of sugarcane families across variable environments II. Patterns of response and association with environmental factors. Field Crops Research 43, 119-130.

Jandel Scientific. 1991. Table Curve v. 3.0. User's manual version 3.0 AISN software. Corte Madera, CA: Jandel Scientific.

Kang MS, Miller JD, Tai PYP, Dean JL, Glaz B. 1987. Implications of confounding of genotype $\times$ year and genotype $\times$ crop effects in sugarcane. Field Crops Research 15, 349-355.

Kang MS, Sosa O, Miller JD. 1990. Genetic variation and advance for rind hardness, flowering and sugar yield traits in sugarcane. Field Crops Research 23, 69-73. 
Keating BA, Robertson MJ, Muchow RC, Huth NI. 1999. Modelling sugarcane production systems. I. Development and performance of the sugarcane module. Field Crops Research 61, 253-271.

Li YR. 2004. Beneficial effects of ethephon application on sugarcane under sub-tropical climate of China. SugarTech 6, 235-240.

Lingle SE, Irvine JE. 1994. Sucrose synthase and natural ripening in sugarcane. Crop Science 34, 1279-1283.

Lingle SE, Smith RC. 1991. Sucrose metabolism related to growth and ripening in sugarcane internodes. Crop Science 31, 172-177.

Lingle SE, Tew TL. 2008. A comparison of growth and sucrose metabolism in sugarcane germplasm from Louisiana and Hawaii. Crop Science 48, 1155-1163.

Lingle SE, Viator RP, Johnson RM, Tew TL, Boykin DL. 2009. Recurrent selection for sucrose content has altered growth and sugar accumulation in sugarcane. Field Crops Research 113, 306-311.

Liu DL, Kingston G, Bull TA. 1998. A new technique for determining the thermal parameters of phenological development in sugarcane, including suboptimum and supra-optimum temperature regimes. Agricultural and Forest Meteorology 90, 119-139.

Mamet LD, Domaingue R, Cheeroo-nayamuth F. 1996. Research and development on earliness of ripening of sugarcane (Saccharum spp.) at the Mauritius sugar industry research institute. In: Anon. Proceedings of the South African Sugar Technologists Association, vol. 70. Mauritius: Mauritius Sugar Research Institute, 106-110.

Mamet LD, Galwey NW. 1999. A relationship between stalk elongation and earliness of ripening in sugarcane. Experimental Agriculture 35, 283-291.

Marchiori PER, Machado EC, Ribeiro RV. 2014. Photosynthetic limitations imposed by self-shading in field-grown sugarcane varieties. Field Crops Research 155, 30-37.

Marchiori PER, Ribeiro RV, Silva L, Machado RS, Machado EC, Scarpari MS. 2010. Plant growth, canopy photosynthesis and light availability in three sugarcane varieties. SugarTech 12, 160-166.

Mariotti JA. 2001. Selection for sugar cane yield and quality components in subtropical climates. International Sugar Journal 103, 418-423.

Mariotti JA, Sopena RA, Ullivarri E, Rago AM, Terán CH, Collavino NG, Pocovi MI, Simón GE. 2006. Breeding and sustainable crop management as the basis for competitiveness of sugar cane production in Argentina. SugarTech 8, 217-223.

McCormick AJ, Watt DA, Cramer MD. 2009. Supply and demand: sink regulation of sugar accumulation in sugarcane. Journal of Experimental Botany 60, 357-364.

Meade GP, Chen JCP. 1977. Cane sugar handbook: a manual for cane sugar manufacturers and their chemists. New York: Wiley.

Milligan SB, Martin FA, Bischoff KP, et al. 1994. Registration of LCP 85-384 sugarcane. Crop Science 34, 819-820.

Ming R, Moore PH, Wu KK, D’Hont A, Glaszmann JC, Tew TH. 2006. Sugarcane improvement through breeding and biotechnology. In:Janick $\mathrm{J}$, ed. Plant Breeding Review, vol. 27. New Jersey: John Wiley and Sons, Inc., $15-118$

Moore PH. 1995. Temporal and spatial regulation of sucrose accumulation in the sugarcane stem. Functional Plant Biology 22, 661-679.

Moore PH. 2005. Integration of sucrose accumulation processes across hierarchical scales: towards developing an understanding of the gene-tocrop continuum. Field Crops Research 92, 119-135.

Moore PH, Botha FC. 2013. Sugarcane: physiology, biochemistry, and functional biology. lowa: John Wiley \& Sons, Inc.

Moyle RL, Birch RG. 2013. Sugarcane loading stem gene promoters drive transgene expression preferentially in the stem. Plant Molecular Biology $\mathbf{8 2}$ 51-58.

Muchow RC, Robertson MJ, Wood AW. 1996a. Growth of sugarcane under high input conditions in tropical Australia. II. Sucrose accumulation and commercial yield. Field Crops Research 48, 27-36.

Muchow RC, Robertson MJ, Wood AW, Keating BA. 1996b. Effect of nitrogen on the time-course of sucrose accumulation in sugarcane. Field Crops Research 47, 143-153.

Muchow RC, Spillman MF, Wood AW, Thomas MR. 1994. Radiation interception and biomass accumulation in a sugarcane crop grown under irrigated tropical conditions. Australian Journal of Agricultural Research $\mathbf{4 5}$ $37-49$.
O'Leary GJ. 2000. A review of three sugarcane simulation models with respect to their prediction of sucrose yield. Field Crops Research 68, 97-111.

Ramburan S. 2014. A multivariate illustration and interpretation of nonrepeatable genotype $\times$ environment interactions in sugarcane. Field Crops Research 157, 57-64

Ramburan S, Wettergreen T, Berry SD, Shongwe B. 2013. Genetic, environmental and management contributions to ratoon decline in sugarcane. Field Crops Research 146, 105-112.

Ramburan S, Zhou M, Labuschagne M. 2011. Interpretation of genotype $\times$ environment interactions of sugarcane: identifying significant environmental factors. Field Crops Research 124, 392-399.

Ribeiro RV, Machado EC, Magalhães Filho JR, Lobo AK, Martins MO, Silveira JA, Yin X, Struik PC. 2017. Increased sink strength offsets the inhibitory effect of sucrose on sugarcane photosynthesis. Journal of Plant Physiology 208, 61-69.

Ritchie JT, Ne Smith DS. 1991. Temperature of crop development. In: Hanks J, Ritchie JT, eds. Modeling plant and soil systems. Agronomic Monograph no. 31. Madison, WI: ASA, CSSA, SSSA, 5-29.

Romero ER, Scandaliaris J, Rufino M, Pérez Zamora F. 2001 Biothermal models to predict plant cane amergence. In: Hogarth DM, ed. Proceedings of the XXIV ISSCT Congress, vol. 24. Brisbane, Australia: ISSCT, 95-100.

Sabatier D, Martiné J-F, Chiroleu F, Roussel C, Letourmy $\mathbf{P}$, van Antwerpen R, Gabrielle B, Ney B. 2015. Optimization of sugarcane farming as a multipurpose crop for energy and food production. GCB Bioenergy 7, 40-56.

Sinclair TR, Gilbert RA, Perdomo RE, ShineJr. JM, Powell G, Montes G. 2004. Sugarcane leaf area development under field conditions in Florida, USA. Field Crops Research 88, 171-178.

Sinclair TR, Gilbert RA, Perdomo RE, Shine JM, Powell G, Montes G. 2005. Volume of individual internodes of sugarcane stalks. Field Crops Research 91, 207-215.

Singels A. 2013. Crop models. In: Moore PH, Botha FC, eds. Sugarcane: physiology, biochemistry, and functional biology. Iowa, USA: John Wiley \& Sons Ltd., 541-577.

Singels A, Bezuidenhout CN. 2002. A new method of simulating dry matter partitioning in the Canegro sugarcane model. Field Crops Research 78, 151-164.

Singels A, Donaldson RA, Smit MA. 2005a. Improving biomass production and partitioning in sugarcane: theory and practice. Field Crops Research 92, 291-303.

Singels A, Smit MA. 2002. The effect of row spacing on an irrigated plant crop of surgarcane variety NCO376. In: Anon, ed. Proceedings of the South African Sugar Association, vol. 76. Mount Edgecombe, South Africa: SASA, 94-105.

Singels A, Smit MA. 2009. Sugarcane response to row spacing-induced competition for light. Field Crops Research 113, 149-155.

Singels A, Smit MA, Redshaw KA, Donaldson RA. 2005b. The effect of crop start date, crop class and cultivar on sugarcane canopy development and radiation interception. Field Crops Research 92, 249-260.

Singh RK, Singh SB. 2004. Breeding strategies for commercially elite early maturing varieties of sugarcane (Saccharum species complex). SugarTech 6, 89-92.

Smit MA. 2011. Characterising the factors that affect germination and emergence in sugarcane. International Sugar Journal 113, 65-67.

Sopena RA, Felipe A, Rago A, Erazzú LE, Perez-Gomez SG, Fontana PD, Mariotti JA, Di-Pauli V. 2015. Nuevas variedades de caña de azúcar desarrolladas por el INTA Famaillá. In: Anon, ed. Cultivos industriales. Famaillá: INTA, 12.

van Dillewijn C. 1952. Botany of sugarcane. Waltham, MA: The Chronica Botanica Co.

van Heerden PDR, Mbatha TP, Ngxaliwe S. 2015. Chemical ripening of sugarcane with trinexapac-ethyl (Moddus ${ }^{\circledR}$ ) Mode of action and comparative efficacy. Field Crops Research 181, 69-75.

Vasantha S, Gupta C, Shekinah DE. 2014. Physiological studies on tiller production and its senescence in sugarcane - Response comparison between plant and ratoon crops. Indian Journal of Agricultural Sciences 84, 24-27. 
Vasantha S, Shekinah DE, Gupta C, Rakkiyappan P. 2012. Tiller production, regulation and senescence in sugarcane (Saccharum species hybrid) genotypes. SugarTech 14, 156-160.

Verma I, Roopendra K, Sharma A, Jain R, Singh RK, Chandra A. 2017. Expression analysis of genes associated with sucrose accumulation in sugarcane under normal and GA3-induced source-sink perturbed conditions. Acta Physiologiae Plantarum 39, 133.

Waclawovsky AJ, Sato PM, Lembke CG, Moore PH, Souza GM. 2010. Sugarcane for bioenergy production: an assessment of yield and regulation of sucrose content. Plant Biotechnology Journal 8, 263-276.

Wang J, Nayak S, Koch K, Ming R. 2013. Carbon partitioning in sugarcane (Saccharum species). Frontiers in Plant Science 4, 201.
Warne RT. 2014. A primer on multivariate analysis of variance (MANOVA) for behavioral scientists. Practical Assessment, Research and Evaluation 19, 1-10.

Whittaker A, Botha FC. 1997. Carbon partitioning during sucrose accumulation in sugarcane internodal tissue. Plant Physiology 115, 1651-1659.

Ye R, Wright AL. 2010. Multivariate analysis of chemical and microbial properties in histosols as influenced by land-use types. Soil and Tillage Research 110, 94-100.

Zuccardi R, Fadda G. 1985. Bosquejo agrológico de la provincia de Tucumán, vol. 86. Tucumán, Argentina: Facultad de Ciencia Agrarias, Universidad Nacional de Tucumán, 1-55. 